санкції мали б досягти такого ж ефекту. Більше того, досвід багатьох юрисдикцій показує, що цивільно-правові та адміністративно-правові санкції більше підходять як відповідь на «підбурювання». Такі санкції також важливі, оскільки вони передбачають залучення та участь жертв та передбачають конкретне відшкодування для них. У той же час, ці санкції слід оцінювати для того, щоб «уникнути ситуації, коли обмеження, спрямовані на захист меншин від жорстокого поводження, екстремізму чи расизму, мають згубний ефект цензора опозиції та окремих голосів, приглушення меншин та посилення домінуючого політичного, соціального та морального дискурсу та ідеології».

\title{
Література:
}

1. Міжнародний пакт про громадянські і політичні права від 16 грудня 1966 року. URL: https://zakon.rada.gov.ua/laws/show/995_043 (дата звернення: 04.02.2021)

2. Рекомендації стосовно тлумачення та імплементації статті 20(2) Міжнародного пакту про громадянські та політичні права. URL: https://www.ohchr.org/Documents/Issues/Expression/ICCPR/Vienna/ CRP7Callamard.pdf

3. Domestic Implementation of the InternationalCovenant on Civil and Political Rights Pursuantto its article 2 para. URL: https://www.mpil.de/ files/pdf1/mpunyb_seibert_fohr_5.pdf

DOI https://doi.org/10.30525/978-9934-26-040-7-61

\section{ПРОБЛЕМА НАЦІОНАЛЬНОЇ ДОКТРИНИ МІЖНАРОДНОГО ПРАВА: ВІЗІЯ ФРАНЦУЗЬКИХ ЮРИСТІВ-МІЖНАРОДНИКІВ}

\author{
Микитенко О. В. \\ аспірант кафедри міжнародного права \\ Львівського начіонального університету імені Івана Франка \\ м. Львів, Украӥна
}

Вступ. Іспанський учений А. Труйоль і Серра, у своїй науковій праці французькою мовою акцентував: «Якщо вірно, що певні течії думки особливо пов'язані з національними філософськими або науковими традиціями, не менш вірно і те, що наука про право народів $\epsilon$ міжнародною не тільки через природу іiі об'єкта, а через обов'язкову 
взаємозалежність доктрин однієї країни з іншою» [1]. Зазвичай, не ставиться під сумнів існування і багатство праць французьких юристівміжнародників, але ставиться їх специфічний характер. Питання полягає у можливості ідентифікації й систематизації творів французьких авторів шляхом їх об'єднання чи протиставлення відповідно до їх доктринальних тенденцій або їх диференціювання у відносній однорідності в порівнянні з іншими іноземними міжнародно-правовими доктринами. Наукова проблема існування сучасної французької доктрини міжнародного права полягає в аналізі участі французьких юристів-міжнародників у розвідках наукових шкіл, ініційованих відомими юристами, здебільшого - європейськими, чиї ідеї стали інтернаціоналізованими. Такий аналіз здійснюється 3 метою формування загального доктринального фонду, який буде важко пов'язати з тією чи іншою національною традицією, оскільки розробки науковців будуть носити загальний характер.

Виклад матеріалу. На відміну від внутрішньоправової французької доктрини, яка розвинула дуже специфічні тенденції, наприклад, у порівнянні з німецькою правовою традицією, і яка, крім того, мала беззаперечні наслідки для міжнародно-правових теорій, на думку французького вченого Е. Жуане, французька доктрина міжнародного права через своє походження, історію, проникність до течій та ідей i, особливо, через свій об'єкт, не може не бути представленою, особливо сьогодні - в період значного доктринального оновлення.

Ш. Русо у 1958 р. відзначав переоцінку національної концепції міжнародного права $[2,3]$. Проте, в певний період французької історії загострений національний дух спонукав деяких юристів-міжнародників наполягати на створенні французької школи міжнародного права. У 1905 р. Ф. Депанье пояснював: «Ми повинні створити французьку школу міжнародного права: інтереси нашої країни можуть багато у цьому виграти, не втрачаючи при цьому неупередженості, духу розуму і справедливості, які характеризують нашу націю, дозволяють нам стверджувати, що захист наших законних інтересів залишає нам, можливо, більше, ніж усім іншим, ясне поняття права 3 твердою волею поважати його і служити йому» [4].

На думку Е. Жуане, поняття сучасної французької доктрини міжнародного права як окремої категорії, не обов'язково має відношення до міжнародно-правової думки і самого міжнародного права, тому що воно, ймовірно, не дає певного способу розуміння нинішньої міжнародно-правової реальності. Здійснений аналіз дозволяє стверджувати, що висловлені позиції науковців породжують певне національне бачення міжнародного права, але не мають реального значення для юридичної науки. Це означало б, що сучасна французька доктрина, 242 
можливо, не відповідає моделі операційного мислення, яка представляє доктринальну специфіку, достатню для того, щоб мати прямий інтерес і ефект для розуміння міжнародного права [5].

Проте, необхідно згадати таких учених, як Х. Бонфіса і Л. Ле Фура, які захищали дисциплінарну патріотичну концепцію через франконімецький спір. Юристи-міжнародники завжди чуйно ставляться до того, як міжнародне право застосовується в їхній власній країні та їхньою країною, а відтак можуть, свідомо чи несвідомо, надавати перевагу національній зовнішній політиці своєї держави в своєму розумінні й сприйнятті права [5].

Сумніви щодо існування тієї чи іншої французької доктрини міжнародного права можуть, також, здивувати, оскільки французькі вчені звикли посилатися на певну традицію думки або, принаймні, пропонувати трактування, що є іiї частиною. Про це сьогодні свідчить існування досить добре ідентифікованої спільноти французьких юристівміжнародників, роботи яких, очевидно, є частиною іiї власної наукової течії. Ідеться про створення в 1967 р. Французького товариства міжнародного права, метою діяльності якого $є$ сприяння вивченню та розвитку міжнародного права. Не слід також забувати й французькі журнали 3 міжнародного права, у т. ч. фахові, та інші періодичні видання, у яких висловлюються французькі міжнародно-правові думки, зокрема «Revue générale de droit international public» («Загальний огляд міжнародного публічного права»), «Journal du droit international» («Журнал 3 міжнародного права») і «Annuaire français de droit international» («Щорічне французьке видання з міжнародного права»).

Висновки. Серед французьких учених є дві діаметрально протилежні науково-правові позиції стосовно проблем національної доктрини міжнародного права. Ф. Депаньє, Х. Бонфіс і Л. Ле Фур $є$ прихильниками національної концепції міжнародного права, у той час як Ш. Русо - противник переоцінки національної концепції міжнародного права. Самі французькі дослідники охоче визнають, що відчувають зв'язок приналежності до власної національної доктрини, хоча це почуття здається погано визначеним, навіть майже ірраціональним, оскільки воно не грунтується на точних критеріях [5]. Діяльність Французького товариства міжнародного права і наукові видання, такі як «Revue générale de droit international public» («Загальний огляд міжнародного публічного права»), «Journal du droit international» («Журнал 3 міжнародного права») i «Annuaire français de droit international» («Щорічне французьке видання з міжнародного права»), свідчать на користь позиції прихильників національної концепції. 


\title{
Література:
}

1. A. Truyol y Serra. Doctrines contemporaines du droit des gens. Cours IHEI. Paris: 1952. C. 6.

2. Ch. Rousseau. Principes de droit international public. RCADI. 1958. C. 375.

3. Ch. Rousseau. Les conceptions nationales du droit des gens. Pedone. Paris: 1981. P. 441-446.

4. F. Despagnet. Cours de droit international public. Librairie générale des lois et arrêts. Paris: 1905. № 3. P. 6.

5. Jouannet Emmanuelle. Regards sur un siècle de doctrine française $\mathrm{du}$ droit international. Annuaire français de droit international. 2000. № 46. P. 1-57.

DOI https://doi.org/10.30525/978-9934-26-040-7-62

\section{ДЖЕРЕЛА ЕКОЛОГО-ПРАВОВОГО ЛІМІТУВАННЯ СКИДАННЯ РЕЧОВИН У ЗАКОНОДАВСТВІ ЄС ТА УКРАЇНИ}

\author{
Уберман B. I. \\ кандидат технічних наук, \\ провідний науковий співробітник лабораторї формування \\ та регулювання якості вод \\ Науково-дослідної установи \\ «Украӥнський науково-дослідний інститут екологічних проблем» \\ м. Харків, Украӥна \\ Васьковець Л. А. \\ кандидат біологічних наук, доцент, \\ професор кафедри безпеки праиі і навколишнього середовища \\ Начіонального технічного університету \\ «Харківський політехнічний інститут» \\ м. Харків, Украӥна
}

1. У документі державної екологічної політики України $[1$, p. 1] (Стратегія) серед головних проблем вказано забруднення вод, значне місце в якому займають «скиди 3 промислових об'єктів». Боротьба зі скидами речовин включає заходи щодо забезпечення якості води та 